\title{
Detection of Corona virus antigen by ELISA from diarrhoeic cow calves in Mathura, I ndia
}

\author{
S K Dash*, K Kumar, A Goel and A K Bhatia \\ Department of Veterinary Microbiology and Immunology, \\ College of Veterinary Sciences and Animal Husbandry, \\ Pandit Deen Dayal Upadhyaya Veterinary and Animal Science University, Mathura-281001, UP, India \\ * Corresponding author email: sandeepkumar.dash@gmail.com \\ Received: 09-08-2011, Accepted: 11-09-2011, Published Online: 18-12-2011 \\ doi: $10.5455 /$ vetworld.2012.166-168.
}

\begin{abstract}
Neonatal diarrhoea is one of the most important conditions of calves, associated with morbidity and mortalities. Diarrhoeal diseases have an adverse effect on calf health status, survival and productive performances. Corona virus is one of the etiological agents responsible for calf diarrhea worldwide. However there is paucity of literature stating the disease status in India. The present study was carried out to determine the prevalence of corona virus infection among cow calves in Mathura and adjacent regions. During the present study 63 diarrhoeic stool samples collected from cow calves were screened for corona virus. Of the 63 diarrhoeic samples 3 samples (4.76\%) were found to be positive for corona virus by ELISA.
\end{abstract}

Keywords: Bovine corona virus; Rotavirus; Diarrhoea; ELISA.

\section{To cite this article :}

Dash SK, Krishna K, Goel A, Bhatia AK (2012) Detection of Corona virus antigen by ELISA from diarrhoeic cow calves in Mathura, India, Vet. World. 5(3): 166-168, doi: 10.5455/vetworld.2012.166-168.

\section{Introduction}

Major etiological agents responsible for calf diarrhoea are bacteria (E. coli, Salmonella), Viruses (Rotavirus, corona virus) and protozoa (Cryptosporidia) [4]. Corona viruses and rotaviruses are the most common viruses involved in neonatal calf diarrhoea. Coronaviruses belong to family Coronoviridae. Coronavirus particles are irregularly-shaped, $80-220 \mathrm{~nm}$ in diameter, with an outer envelope bearing distinctive, 'clubshaped' peplomers (20 nm long). This 'crownlike' appearance (Latin, corona) gives the family its name.

The Viruses have non-segmented, singlestranded RNA with helical symmetry [5]. Corona viral diarrhea in young calves is characterized by profuse watery or hemorrhagic diarrhoea lasting for 2 to 6 days along with listlessness, anorexia, pyrexia, and dehydration. Morbidity is high (30$100 \%$ ) but mortality is influenced by the age of the calf. Calves with bloody diarrhoea can die of hypovolemia within a few hours of the onset of clinical signs [1].

Viral transmission can be through aerosols of respiratory secretions, via the faecal-oral route, or by mechanical transmission [1].

\section{Materials and Methods}

Collection of specimens: A total of 63 diarrhoeic fecal samples were collected from calves from both organized and non-organized dairy farms located in and around Mathura during winter months of the study period, 2007-2009. The stool samples were collected in sterilized plastic containers, transported under ice and stored at $20^{\circ} \mathrm{C}$ till further processing.

Screening by ELISA: ELISA was performed to detect corona virus antigen in the fecal samples as described by the kit manufacturer (Corona virus ELISA kit, Bio-X Diagnostics, Belgium). The 96 
well plates provided in the kit contained two different capture antibodies. Rows A, C, E and G were coated with corona virus specific capture antibodies and rows B, D, F, H coated with nonspecific antibodies, which acted as controls. These control rows allow the differentiation between specific immunological reaction and non-specific bindings so as to eliminate false positives. Faeces were diluted in the dilution buffer provided in the kit. A volume of $100 \mu 1$ of diluted sample was added to corresponding wells of specific and nonspecific antibody coated rows respectively. The plate was incubated for one hour at $25^{\circ} \mathrm{C}$ and washed 3 times with washing solution (diluted in the ratio 1:20 with distilled water) provided in the kit. The conjugate, a corona virus specific monoclonal antibody labeled peroxidase was used as such and poured in $100 \mu$ l quantities per well. The plate was incubated for one hour at $25^{\circ} \mathrm{C}$ in a dark room and washed thrice with the washing buffer.

Then $100 \mu$ l of chromogen (tetramehtylbenzidine) were added and the plates allowed to stand at room temperature without excess light for 10 minutes. Finally the reaction was stopped by adding stop solution (1M phosphoric acid) provided in the kit. The optical density was measured at $450 \mathrm{~nm}$ after stopping the reaction with $50 \mu \mathrm{l}$ of stop solution. The test was validated using the positive control and data sheet provided by the kit. The net optical density of each sample was calculated by subtracting the reading for each sample well from corresponding negative control.

Net optical density (O.D.) = O.D. of specific binding - O.D. of non-specific binding. Any sample that yieldied an O.D difference of 0.15 or greater was considered positive.

\section{Results and Discussion}

Till today a variety of methods are used to detect bovine corona virus (BCV) infection in stool samples. Currently used methods include electron microscopy, haemagglutination test, enzyme immune assay, virus isolation in cell culture and RT PCR. Each method has its own advantage and disadvantage. Electron microscopy
(EM) is very expensive and identifies only complete BCV particles accurately. Partial or complete loss of spikes on the viral envelope which occurs during sample processing can mislead the diagnosis [11]. In spite of this EM is still used as a basic test procedure [7]. The results of haemmaglutination test are affected by nonspecific agglutinins present in the faeces [2]. Virus isolation based tests are laborious and time consuming. RT PCR based tests are highly sensitive and widely accepted. For this, good RNA handling facilities, proper standardisation and appropriate positive controls are required. The results of enzyme immunoassays largely depend on the quality of reagents. Polyclonal antibody based tests produce high levels of nonspecific back ground and cross reactions with other antigens present. However, monoclonal antibody based tests overcome these difficulties and are widely used [7]. In the present study we have analyzed fecal samples obtained from single diarrhoeic episodes.

Out of the 63 diarrhoeic stool samples processed, $3(4.76 \%)$ were found positive by ELISA. Other studies also revealed that prevalence of corona virus in neonatal calf diarrhoea is slightly lower than that of rotavirus and varieed between 3.64 to $54 \%$. [8, 10 and 12]. However, there is paucity of literature stating the corona virus prevalence status in India. As per Niture et al. [6] prevalence of rotavirus induced diarrhea in calves varied between 7.49 to $43 \%$ in India. Previous work by our group in the same Mathura and adjacent regions during same study period showed a rotavirus prevalence of $16.83 \%$ [3]. Hence prevalence of corona virus induced diarrhea is less compared to that of rotavirus in the studied regions during this study period (2007-2009). In addition to neonatal diarrhea, bovine corona viruses cause winter dysentery in adult cattle and respiratory tract infections in calves and feed lot cattle [1,2 and 9$]$.

In conclusion, corona viruses are associated with multiple bovine disease conditions and should as a result not be neglected, but consistently monitored and controlled. Monoclonal antibody based ELISAs are simple and easy to perform, 
and are ideal for utilization when generating important epidemiological data.

\section{Acknowledgements}

Authors are thankful to the Department of Veterinary Microbiology, Pt. Deen Dayal Upadhayaya Veterinary and Animal Sciences University (DUVASU), Mathura, UP, India for providing necessary facilities to carry out this research work.

\section{Conflicts of interest}

Authors declare that they have no conflicts of interest.

\section{References}

1. Cho KO, Halbur PG and Bruna JD et al., (2000). Detection and isolation of coronavirus from faeces of three herds of feelotcattle during outbreaks of winter dysentry like disease. J.Am. Vet.Med.Assoc. 217:1191-1194.

2. Clark MA (1993). Bovine coronavirus. Brit. Vet. J., 149, 51-70.

3. Dash SK, Tewari A, Krishna Kumar, Goel A and Bhatia AK (2011). Detection of rotavirus from diarrhoeic cow calves in Mathura, India. Vet. World 4 (12):554-556.

4. Hungerford TG (1990). Diseases of livestock. $9^{\text {th }}$ Ed. McGraw-Hill Book Company, UK, pp. 213.

5. Lai MMC and Holmes KV (2001). Coronaviridae, the viruses and their replication, p. 1163-1185. In DM Knipe, PM Howley, DE Griffin, MA Martin, RA Lamb, B. Roziman and SE Strauss (ed), Fields virology, $4^{\text {th }} \mathrm{ed}$, Lippincott Williams \& Wilkins, Philadelphia,.

6. Niture GS, Karpe AG, Prasad M, Bhonsle $\mathrm{AV}$, Ingale SS. Genomic diversity among Rotaviruses isolated from diarrhoeic buffalo calves. Vet World. 2009; 2:259-260.

7. Reschova S, Pokorova D, Nevorankova Z, Franz J (2001). Monoclonal antibodies to bovine corona virus and their use in enzymoimmunoanalysis and immunochromatography. Vet. MedCzech, 46, (5), 125-131.

8. Reynolds DJ, Morgan JH, Chanter $\mathrm{N}$ et al. (1986). Microbiology of calf diarrhea in southern Britain. Vet. Rec. 119: 34-39.

9. Saif LJ, Brock KV, Redman DR and Kohler EM (1991). Winter dystentry in dairy herds: electron microscopic and serological evidence for an association with coronavirus infection. Vet. Rec. 128:447-449.

10. Simeonov I, Peev Y and Iordanov V (1981). Etiology of enteritis in new born calves in the Varchan region of Bulgaria. Vet. Sbirka. 79:19-23.

11. Smith DR, Tsunemitsu H, Heckert RA, Saif LJ (1996). Evaluation of two antigen-capture ELISAs using polyclonal or monoclonal antibodies for the detection of bovine corona virus. J. Vet. Diagn. Invest., 8, 99-105.

12. Snodgrass DR, Terzolo HR, Campbell D et al (1986). Etiology of diarrhea in young calves. Vet.Rec. 119: 31-34. 